\title{
Research on the Development Trend of Arts Education and the Countermeasure of Art Course Construction
}

\author{
Weimin Zhang \\ Weinan Vocational \& Technical College, Shanxi, Weinan, 714026, China
}

\begin{abstract}
Art education has the imbalance phenomenon. That is to say, our art education has been biased towards scientific rationality in the past. The purpose of this paper is to understand and grasp some tendency of art education, so as to take corresponding measures in some more specific aspects to adapt and promote this development.

Keywords: development trend, arts education, countermeasure, art course construction
\end{abstract}

\section{Introduction}

With the progress of national economy and social life, as well as the implementation of quality education, Chinese art education is also further development. The so-called development refers to the emergence of some new things, on the other hand refers to some factors tend to reasonable adjustments. Any development is manifested as a bias, so it is important to understand and grasp some of the tendencies of art education that will lead us to take appropriate measures in some more specific areas to promote such development. Emotional strengthening is the development of Chinese art education is a very clear trend. This kind of emotional expression is a warm and active, corresponding to the human emotions, intuition, and with the occurrence of interest. The emergence of this momentum in essence, reflects the people's pursuit of balance, in fact, play a regulatory role in the balance mechanism. 
If we want to make our art education more balanced, then the adjustment should be the starting point of scientific rationality, and adjust the direction should be to make it more romantic expression. Since it is a balance of regulation, it means from the bias toward positive, rather than toward another bias. Therefore, the present art education in China should pay more attention to and emphasize the affective nature of art teaching without losing the basic knowledge of subject knowledge.

\section{The development trend of art education}

In many academic disciplines, the attitude of students to each discipline is not the same, depending on the external incentives and internal interests of the differences. In a scientific and rational society, the learning attitude of primary and secondary school students is obviously utilitarian, that is, their learning is directly related to the future life, education and job search. Students regardless of whether they are interested in, must exercise restraint with their will to study hard, this is the external incentive for learning activities. Art learning is no other incentive, because the art of primary and secondary school students on the further studies, students use strong willpower to force their own efforts to learn the art of the possibility is not, unless those born to art there is a great interest in the students. Therefore, art disciplines in the minds of most students to maintain a place, it should be noted that interest in the relationship with the students, that is, to stimulate students to learn the intrinsic interest.

According to the requirements of nine-year compulsory education, art education is accepted by all citizens in primary and secondary schools. Therefore, the whole should be said that the basic attributes of basic art education. In other words, if only some people accept this art education, or this art education itself can not attract the vast majority of students, and to achieve a certain minimum quality requirements, then our basic art education the whole can not be regarded as a success. In basic art education, it makes the whole realization possible. Second, the goal of the development of art education The goal of modern art disciplines should not only narrow sense of subject knowledge and skills to achieve, but should be combined with human goals, taking into account the subject knowledge and skills at the same time, Implementation of the responsibility. Therefore, we can blend the two to set the subject of fine arts.

(A) to cultivate art interest, master the basic art knowledge and techniques in the use of art media experience the performance of the fun.

(B) to develop the ability to feel, the ability to operate and create awareness, the development of personality, improve personality.

(3) to understand the heritage of human art, to expand cultural horizons, cultivate artistic appreciation and aesthetic taste.

(D) to understand the relationship between art and life, improve the quality of life.

We deliberately cultivate the interest of art in the art subject, aiming at harmonizing with the affective momentum of art education and reflecting the 
pursuit of balance. This is not an optional embellishment, and indeed an indispensable one important goal. Imagine if a student is not interested in art after art learning, but more and more dislike art, our art education can be said to be successful? If, students through the basic education stage of art learning, to cultivate pairs of art of lifelong interest, it will be a great success of art education. To cultivate art interest as a goal, will enable teachers in their own teaching, consciously through various means to achieve this goal. Moreover, some of the foreign art curriculum objectives have also been included in the cultivation of art interest.

The coverage of these subjects is generally not a problem and the key is to reduce its requirements and difficulty. Moreover, some of the content of the trade-offs is also a question worthy of study. For example, as the bright and dark tone sketch, the current domestic junior high school art teaching syllabus there is a clear requirement, but also reflected in many textbooks. In fact, due to knowledge ability, teaching time and conditions, students really want to understand and master this technique is very small, the teaching effect is often poor. If you want to retain this content, you must reduce the requirements and difficulty, there is no need to reluctantly allow students to understand the complex rules of light and dark tone, and take a simple method of shading to express the volume of objects and bumps, students may be easier to grasp. Similarly, the performance of conditional colour is also a very difficult problem and the choice should also be seriously considered.

\section{The development trend of art education content}

Discipline content must be organized in order to form a teaching content system to meet the needs of the development of the times to form the overall teaching activities. We have too much emphasis on the rigor of teaching content organization logic to the subject of knowledge system instead of teaching content system, for the sake of the overall logic of strict sacrifice very valuable specific teaching content. In fact, the disciplinary knowledge system and discipline education content system is different. Subject knowledge system is a logical combination of disciplinary knowledge, which is not affected by other external factors; while the content system of discipline education must consider the factors such as time, environment and students. The knowledge system of art disciplines is more special, in the history of the centre of the prevailing discipline, foreign art courses on the theory of those who worry about it, because the logic of art disciplines of knowledge, after all, than the logic of scientific knowledge to loose logic Much more. Therefore, the extreme to consider the logic of art disciplines of knowledge, teaching more harm than good.

In fact, the pursuit of fine art teaching content organization logic of the rigor and integrity, the results are often counterproductive. Because the design of any curriculum must take into account the specific implementation of the environment and conditions, the design of re-strict and then complete the course, if implemented in a decentralized environment, its tightness and integrity will 
cease to exist. Art courses are faced with such a decentralized environment. Art classes in the primary school for two per week, in the middle of the week for each week, there is a long period between art classes, and this cycle to carry out a number of other courses, as well as school and family activities, Students of the fun and thinking did not give art alone. After this cycle, when the students face art again, we painstakingly designed courses tightness and integrity, there will be? In all fairness, we can not wishful thinking that each student will be like a professional all day thinking is the art problem. Since the fine and then complete art courses will become loose in the specific teaching environment, then we have to pursue it and how much sense? Instead, it is better to focus more on specific topics carefully designed, so that students in each specific teaching activities have been received.

Of course, we do not completely exclude the logic of teaching content organization, but to dilute it. In fact, a large logical relationship is also essential. Large logical relationship is mainly a number of context, some knowledge and skills to master, must be based on other more basic knowledge and skills, based on, not difficult and he, this logical relationship is essential. In the organization of teaching contents, attention must also be paid to arranging the guiding goals associated with the will and the expressive goals associated with the emotion alternately to form a rhythm change.

\section{The countermeasures of future art curriculum construction}

\subsection{The combination of selected knowledge content and lively interesting subject forms}

From the basic requirements of the discipline, select those essential for future development of the knowledge and skills as the basic knowledge of teaching materials, and their close to the student life experience, novel and lively, interesting and interesting form of the subject together.

\subsection{Highlight the teaching method to guide the preparation of materials}

The current art teaching materials mainly show the knowledge and skills of the discipline, not reflecting the teaching method. Teachers' teaching methods are mainly obtained through other teaching reference books. Such a teaching material is not conducive to enhancing the initiative of student learning, and the cultivation of human goals run counter to. Students should be based on the law of art learning, in each lesson design, show students thinking, master the skills of the process, that is, by questioning, asked questions in the form of students through their own initiative close to the correct answer. 


\subsection{Strengthen the flexibility to adapt to different students}

This set of materials to try to make every student can get a sense of success. Therefore, the teaching materials in the overall lower requirements and difficulty of the circumstances, in each of the knowledge and techniques are set with a certain level of the target, the teacher can be based on the actual level of each student to achieve some of the most basic goals, To encourage them to move as much as possible through the efforts to a higher level goal. In this way, students achieve some basic goals, you can get a sense of success, and if you want to get a greater sense of success, you must work harder..

\subsection{Use a variety of media teaching materials}

Modern education is increasingly influenced by the media, and modern education to maximize the role, we must also rely on the increasingly sophisticated media. For a long time, I am afraid text and images constitute textbooks is still a basic textbook form, but to enhance the diversity of information stimulation, access to specific teaching effects, we must also use other media. Therefore, this set of textbooks in the textbook as the basic form at the same time, you can also create the appropriate video and multimedia teaching software.

\section{Conclusion}

The new situation has promoted the development of art education and the development of art education requires us to make all kinds of thinking and response. This article put forward immature insights on the development of art education in order to lead to further thinking in order to more deeply and accurately grasp the relevant issues and promote our art education reform.

\section{References}

[1] Zhan Yi. Taiwan modern children's art education early education (art edition), 55(12), pp.68-70, 2011

[2] Wang Huiyu. Japanese art education knowledge .Art and contention, 8 (5), pp.87-91, 2013

[3] Yin Shao-chun. Art Education Interpretation. Art Observation, 12(10), pp. 1820, 2012

[4] Qian Chu-hei. Japan, the concept of art education and methods of change. China Art Education, 9(6), pp.58- 61, 2011

[5] Chen Yueli. Parents misunderstandings in children's art education. Big stage art bimonthly, 8(4), pp.85-87, 2014 